\title{
The Influence of Teaching Vocabulary by Using Picture
}

\author{
Hanik Nuzulimah \\ MTs Walen \\ Simo Boyolali \\ Haniknuzulimah@gmail.com
}

\begin{abstract}
This paper attempts to explore whether there is significant difference of achievement in vocabulary between students taught by using pictures and those are not. The subject of this study is the first year students of SLTP Muhammadiyah Simo Susukan, Semarang where the sample contains 50 students that is divided into experimental group (with treatment) and control group (without treatment). The data is gathered from participants' score obtained from pre test and post test. Using t test as technique of data analysis, result shows that students taught by using pictures perform better than those are not. It means that there is significant difference between the two groups.
\end{abstract}

Keywords: Vocabulary Teaching, Picture

\begin{abstract}
Abstrak
Tulisan ini mencoba untuk meneliti apakah ada perbedaan yang signifikan pada prestasi dalam penguasaan kosakata bahasa Inggris antara siswa yang diajarkan dengan menggunakan gambar dan mereka yang tidak. Subjek penelitian ini adalah siswa tahun pertama SLTP Muhammadiyah SimoSusukan, Semarang di mana sampel terdapat 50 siswa yang dibagi menjadi kelompok eksperimen (dengan treatment/tindakan) dan kelompok kontrol (tanpa treatment). Data tersebut dikumpulkan dari skor peserta yang diperoleh dari pre test dan post test. Menggunakan $t$ test sebagai teknik analisis data. Hasil menunjukkan bahwa siswa yang diajarkan dengan menggunakan gambar, lebih baik daripada mereka yang tidak. Ini berarti bahwa ada perbedaan yang signifikan antara kedua kelompok.
\end{abstract}

Keywords: Pengajaran Kosakata, Gambar 


\section{Introduction}

Vocabulary, in English, is taught at school to provide language skill for the students, i.e. listening, speaking, reading, and writing. Number of vocabularies mastered can influence the learner to perform his language ability. Robert Lado (1961: 117) states that 2000 words is an adequate minimum number for the speaker in basic communication. However, it will need more in the production level. To fulfill the purpose of English learning,

students are encouraged to study such an element since elementary level to create good quality of language ability. Regarding this, a range of effective technique should be applied.

In this research, the writer uses picture as vocabulary teaching technique to probe since it has not been employed intensively to increase students' vocabulary mastery in secondary level, especially in SLTP Muhammadiyah II Simo Boyolali. In addition, there is no exact measurement about students' ability in vocabulary generally as well as after a specific technique used.

Therefore, as the guidance of the research, the writer formulates the problem statements as follows.

1. How is the vocabulary mastery achieved by students of SLTP Muhammadiyah II Simo Boyolali in the pre-test?

2. How is the vocabulary mastery achieved by students of SLTP Muhammadiyah II Simo Boyolali in the post-test?

3. Is there any significant difference between students taught vocabularies by picture and those are not?

\section{The Definition of Vocabulary}

Vocabulary mastery is considered as the prominent way to succeed in language learning. According to Hornby (1987: 419), it is defined as total number of words in a language that is used by a person. Furthermore, 
vocabularies that are employed in a language are divided into two kinds, i.e. active vocabulary and passive vocabulary. The first one means the words that are used for productive purposes (speaking and writing). Meanwhile, the last is words that are applied in receptive aims (listening and reading).

\section{Picture as Vocabulary Teaching Aid}

As stated by Mackey (1965), there are four classifications of words i.e.:

1. Concrete words, such as pencil, book, and clothes.

2. Abstract words, like jump, run and study.

3. Quality words, such as tall, short, and sour.

4. Structure words, for instance in, on, at, and under.

To teach foreign language learners about those vocabularies and help them store what they have got, teacher should apply certain technique. Using picture during teaching is one way to do such a thing. There are many paths to employ picture as teaching means. Moreover, teachers seem to be familiar with its use in their surroundings such as:

1. Picture in the text

2. Picture in the class, that used to be in the form of flash card or wall picture.

3. Film-strips or slide film, which provides more control of the teacher regarding the arrangement of object and situation.

\section{Television}

Considering a number of the utilization of picture in teaching activity, the writer, in current research, focuses on the usage of picture in the text and flash card to solve the problem statements.

\section{Research Methodology}

Subject of the research is the first year students of SLTP Muhammadiyah Simo, Boyolali in the academic year 2003. Using experimental design, the 
writer took 80 students from two classes randomly as the samples and divided them into two groups; 40 students in the control group (without treatment) and the rest in the experiment group (with treatment). Data were obtained from pre test and post test shared to the participants. Afterward, collected data were analyzed using $t$ test to compare the result between groups and probe the significant difference emerged.

\section{Discussion}

In this stage, the writer provides the data into tables to show the result between groups in the pre and post test that are described as follows.

Table 1. The Result of Pre Test

Experiment group

\begin{tabular}{|l|l|l|l|l|}
\hline No & Score & (f) & (x) & f(x) \\
\hline 1 & $50-54$ & 2 & 52 & 104 \\
2 & $55-59$ & 4 & 57 & 228 \\
3 & $60-64$ & 5 & 62 & 310 \\
4 & $65-69$ & 6 & 67 & 402 \\
5 & $70-74$ & 10 & 72 & 720 \\
6 & $75-79$ & 7 & 77 & 539 \\
7 & $80-84$ & 2 & 82 & 164 \\
8 & $85-89$ & 2 & 87 & 174 \\
9 & $90-94$ & 1 & 92 & 92 \\
10 & $95-99$ & 1 & 97 & 97 \\
\hline & & N:40 & 745 & 2830 \\
& & & & \\
\hline
\end{tabular}

Mean $=\frac{\sum f x}{N}=\frac{2830}{40}=70.75$

\section{Control group}

\begin{tabular}{|l|l|l|l|l|}
\hline No & Score & $(\mathrm{f})$ & $(\mathrm{x})$ & $\mathrm{f}(\mathrm{x})$ \\
\hline 1 & $50-54$ & 1 & 52 & 52 \\
2 & $55-59$ & 2 & 57 & 114 \\
3 & $60-64$ & 3 & 62 & 186 \\
4 & $65-69$ & 8 & 67 & 536 \\
5 & $70-74$ & 8 & 72 & 576 \\
6 & $75-79$ & 11 & 77 & 847 \\
7 & $80-84$ & 4 & 82 & 328 \\
8 & $85-89$ & 2 & 87 & 174 \\
9 & $90-94$ & 1 & 92 & 92 \\
10 & $95-99$ & 0 & 97 & 0 \\
\hline & & $\mathrm{N}: 40$ & 745 & 2905 \\
\hline
\end{tabular}

$$
\text { Mean }=\frac{\sum f x}{N}=\frac{2905}{40}=72.625
$$


Table 2. The Result of Post Test

Experiment group

\begin{tabular}{|l|l|l|l|l|}
\hline No & Score & (f) & (x) & f(x) \\
\hline 1 & $60-64$ & 1 & 62 & 62 \\
2 & $65-69$ & 3 & 67 & 201 \\
3 & $70-74$ & 4 & 72 & 288 \\
4 & $75-79$ & 5 & 77 & 385 \\
5 & $80-84$ & 6 & 82 & 492 \\
6 & $85-89$ & 12 & 87 & 1044 \\
7 & $90-94$ & 6 & 92 & 552 \\
8 & $95-99$ & 3 & 97 & 291 \\
\hline & & N:40 & 636 & 3315 \\
\hline
\end{tabular}

Mean $=\frac{\sum f x}{N}=\frac{3315}{40}=82.875$

The Result of Pre Test and Post Test of Control Group

\begin{tabular}{|c|c|c|c|c|c|}
\hline \multirow{2}{*}{ No } & \multirow{2}{*}{ Name } & \multirow{2}{*}{$\begin{array}{l}\text { Pre-test } \\
\left(\mathrm{y}_{1}\right)\end{array}$} & \multirow{2}{*}{$\begin{array}{l}\text { Post-test } \\
\left(\mathrm{y}_{2}\right)\end{array}$} & \multirow{2}{*}{$\begin{array}{l}\mathrm{Y} \\
\left(\mathrm{y}_{2}-\mathrm{y}_{1}\right) \\
\end{array}$} & \multirow{2}{*}{$\begin{array}{l}\mathrm{Y}^{2} \\
\left(\mathrm{y}_{2}-\mathrm{y}_{1}\right)^{2}\end{array}$} \\
\hline & & & & & \\
\hline 1 & Arifin & 6.5 & 7 & 0.5 & 0.25 \\
\hline 2 & Anwar Rosyid & 5.5 & 7 & 1.5 & 2.25 \\
\hline 3 & Arina Maghfiroh & 6.5 & 7 & 0.5 & 0.25 \\
\hline 4 & Abdul Basir & 6 & 6.5 & 0.5 & 0.25 \\
\hline 5 & Budi Asih & 6 & 7.5 & 1.5 & 2.25 \\
\hline 6 & Eva Ratnawati & 7.5 & 8 & 0.5 & 0.25 \\
\hline 7 & Rajar Budiyanto & 8 & 8.5 & 0.5 & 0.25 \\
\hline 8 & Irhamna & 7.5 & 8.5 & 1.0 & 1 \\
\hline 9 & Irham Fauzi & 8 & 9 & 1.0 & 1 \\
\hline 10 & Listiani & 5.5 & 6 & 0.5 & 0.25 \\
\hline 11 & Muawanah & 5.4 & 7.5 & 2.1 & 4.41 \\
\hline 12 & Misbah & 6 & 7.4 & 1.4 & 1.96 \\
\hline 13 & Mahmudi & 6.8 & 7.3 & 0.5 & 0.25 \\
\hline 14 & Muthoharoh & 6.8 & 8.8 & 2.0 & 4 \\
\hline
\end{tabular}




\begin{tabular}{|l|l|l|l|l|l|}
15 & Nariyah & 7 & 8.0 & 1.0 & 1 \\
\hline 16 & Nur Hikmah & 6.6 & 7.6 & 1.0 & 1 \\
\hline 17 & Priyanto & 7.5 & 8.0 & 0.5 & 0.25 \\
\hline 18 & Sunariyah & 8 & 8.5 & 0.5 & 0.25 \\
\hline 19 & Suroto & 8.5 & 8.5 & 0.0 & 0 \\
\hline 20 & Siti Barokah & 9 & 9.2 & 0.2 & 0.04 \\
\hline 21 & Umi Rofiqoh & 8.6 & 8.8 & 0.2 & 0.04 \\
\hline 22 & Umi Mukaromah & 7.8 & 8.1 & 0.3 & 0.09 \\
\hline 23 & Utami Santoso & 6.5 & 7.5 & 1.0 & 1 \\
\hline 24 & Wahyono & 6.4 & 7.4 & 1.0 & 1 \\
\hline 25 & Winarno & 6 & 6.2 & 0.2 & 0.04 \\
\hline 26 & Zulaikhah & 7.2 & 7.4 & 0.2 & 0.04 \\
\hline 27 & Zulaikhah & 7.4 & 7.8 & 0.4 & 0.16 \\
\hline 28 & Zainuri & 7.3 & 7.9 & 0.6 & 0.36 \\
\hline 29 & Zakiyah Isnaningsih & 7.8 & 8.2 & 0.4 & 0.16 \\
\hline 30 & Zakiyah Magufur & 7.9 & 8.3 & 0.4 & 0.16 \\
\hline 31 & Rianingsih & 7.5 & 7.9 & 0.4 & 0.16 \\
\hline 32 & Yuliasih & 7.5 & 7.5 & 0.0 & 0 \\
\hline 33 & Mulayani & 7.7 & 7.9 & 0.2 & 0.04 \\
\hline 34 & Marya Ulfa & 8 & 8.4 & 0.4 & 0.16 \\
\hline 35 & Muhsin & 8.2 & 8.6 & 0.4 & 0.16 \\
\hline 36 & Endarwati & 6.5 & 6.5 & 0.0 & 0 \\
\hline 37 & Bambang Eko M. & 6.7 & 7.3 & 0.6 & 0.36 \\
\hline 38 & Dedi Purnomo & 7.6 & 7.6 & 0.0 & 0 \\
\hline 39 & Devi Wulandari & 7.8 & 8.3 & 0.5 & 0.25 \\
\hline 40 & Endang Sulasmi & 8.6 & 8.8 & 0.2 & 0.04 \\
\hline & & 287.6 & 312.2 & 24.6 & 25.3 \\
\hline & & & & & \\
\hline
\end{tabular}

Table 4

The Result of Pre Test and Post Test of Control Group

\begin{tabular}{|c|c|c|c|c|c|}
\hline \multirow{2}{*}{ No } & \multirow{2}{*}{ Name } & Pre Test & Post Test & $\mathrm{X}$ & $\mathrm{X}^{2}$ \\
\hline & & $\left(\mathrm{x}_{1}\right)$ & $\left(\mathrm{x}_{2}\right)$ & $\left(\mathrm{X}_{2}-\mathrm{X}_{1}\right)$ & $\left(\mathrm{x}_{2}-\mathrm{x}_{1}\right)^{2}$ \\
\hline 1 & Hari Prasetyo & 6.2 & 6.7 & 0.5 & 0.25 \\
\hline 2 & Azhari Yumar & 6 & 7 & 1 & 1 \\
\hline 3 & Murni & 6.8 & 7.2 & 0.4 & 0.16 \\
\hline 4 & Sunarsih & 5.5 & 6.5 & 1 & 1 \\
\hline
\end{tabular}




\begin{tabular}{|c|l|c|c|c|c|}
5 & Safudin & 7 & 7.3 & 0.3 & 0.09 \\
\hline 6 & Iwan Suryanto & 5.9 & 6.5 & 0.6 & 0.36 \\
\hline 7 & Rika Adriani & 6.9 & 7.3 & 0.4 & 0.16 \\
\hline 8 & Catur Setia B & 7.8 & 8 & 0.2 & 0.04 \\
\hline 9 & Sumadiyo & 6.7 & 8.5 & 1.8 & 3.24 \\
\hline 10 & Lia Nurlita & 7.5 & 8.5 & 1 & 1 \\
\hline 11 & Sanyoto & 7.5 & 8.2 & 0.7 & 0.49 \\
\hline 12 & Rachim & 6 & 8.4 & 2.4 & 5.76 \\
\hline 13 & Feri Irmawanto & 7 & 8.5 & 1.5 & 2.25 \\
\hline 14 & Luthfiana Tri S & 7.2 & 8.6 & 1.4 & 1.96 \\
\hline 15 & Winarsih & 7.5 & 7.5 & 0 & 0 \\
\hline 16 & Angjib & 7.6 & 8.2 & 0.6 & 0.36 \\
\hline 17 & Syamsul M & 7.6 & 9.6 & 2 & 4 \\
\hline 18 & Trima Budiana & 5.4 & 6 & 0.6 & 0.36 \\
\hline 19 & Sudi Amanto & 7.4 & 8.4 & 1 & 1 \\
\hline 20 & Supriyanto & 6.8 & 8.7 & 1.9 & 3.61 \\
\hline 21 & Joko Susilo & 7.3 & 7.8 & 0.5 & 0.25 \\
\hline 22 & Kurniawati & 5 & 7.5 & 2.5 & 6.25 \\
\hline 23 & Zaenal Arifin & 7.8 & 8.8 & 1 & 1 \\
\hline 24 & Slamet Purnomo & 7.8 & 8.8 & 1 & 1 \\
\hline 25 & Setiani & 7.4 & 8.4 & 1 & 1 \\
\hline 26 & Mughnoho & 6.5 & 9.5 & 3 & 9 \\
\hline 27 & Prihaniti & 9.8 & 9.8 & 0 & 0 \\
\hline 28 & Siti Suprihati & 7.4 & 8.4 & 1 & 1 \\
\hline 29 & M. Salimun & 6.5 & 7.8 & 1.3 & 1.69 \\
\hline 30 & Agus Riyanto & 8.5 & 8.6 & 0.1 & 0.01 \\
\hline 31 & M. Agus Salim & 6.3 & 8.7 & 2.4 & 5.76 \\
\hline 32 & Triguna & 8.7 & 9 & 0.3 & 0.09 \\
\hline 33 & Rifa Setiawan & 7.4 & 9.2 & 1.8 & 3.24 \\
\hline 34 & Ana Muzayanah & 6.3 & 7.8 & 1.5 & 2.25 \\
\hline 35 & Siti Badiah & 7.2 & 9.4 & 2.2 & 4.84 \\
\hline 36 & Nur Hasanah & 8 & 8.6 & 0.6 & 0.36 \\
\hline 37 & Budi Santoso & 8.3 & 8.9 & 0.6 & 0.36 \\
\hline 38 & Imam Ghozari & 9.4 & 9.8 & 0.4 & 0.16 \\
\hline 39 & Agus Pamuji & 5.8 & 8.8 & 3 & 9 \\
\hline 40 & Yudi Cahyono & 7.3 & 8.8 & 1.5 & 2.25 \\
\hline & & 283 & 323.3 & 47 & 80.6 \\
\hline
\end{tabular}

The result, furthermore, is formulated to find value of t. it is elaborated as follows. 


$$
\begin{aligned}
& M x=\frac{\sum X}{N}=\frac{47}{40}=1.175 \\
& \sum X^{2}=\sum X^{2}-\frac{\left(\sum X\right)^{2}}{N} \\
& =80.6-\frac{(47)^{2}}{40} \\
& =80.6-55.2 \\
& =25.375 \\
& M y=\frac{\sum Y}{N}=\frac{24.6}{40}=0.615 \\
& \sum Y^{2}=\sum Y^{2}-\frac{\left(\sum Y\right)^{2}}{N} \\
& =25.3-\frac{(24.6)^{2}}{40} \\
& =25.3-15.129 \\
& =10.171
\end{aligned}
$$$$
S \bar{D} \bar{x}=\sqrt{\left[\frac{\sum X^{2}+\sum Y^{2}}{N x+N y-2}\right]} \cdot\left[\frac{1}{N x}+\frac{1}{N y}\right]
$$$$
S D \bar{x}=\sqrt{\left[\frac{25.372+10.171}{40+40-2}\right]} \cdot\left[\frac{1}{40}+\frac{1}{40}\right]
$$$$
S \bar{x}=\sqrt{\left[\frac{35.546}{78}\right]} \cdot\left[\frac{2}{40}\right]
$$$$
S D \bar{x}=\sqrt{0.02279}
$$$$
S D \bar{x}=0.151
$$

$$
t=\frac{M x-M y}{S D \bar{x}}=\frac{1.175-0.615}{0.151}=3.708
$$

Earlier, the writer hypothesizes that students taught by using pictures perform better than those taught without it. Based the analysis, the result of $t$ 
observed is 3.708 while the degree of freedom of 78 is 1.668 at the level of significance 0.05 . It means that $\mathrm{t}$ observed is more than the critical value. Therefore, the $\mathrm{H} 0$ is rejected as described as follows.

$1.668<3.708$

(0.05) $t$

Based on the fact that Ho is rejected, it shows that there is significant difference of achievement on vocabulary between students taught using picture and those are not.

\section{Achievement of the Control Group}

From the analysis conducted, students in the experiment group perform better than students in the control group. It is seen from the improved score made by experiment group in the post test. In turn, it means that teaching vocabulary using pictures is one of the best ways to improve vocabulary mastery.

The finding of the research is in line with Kreidler who states that there is amount of advantages using picture as teaching media described as follows.

1. Reminding a real life

2. Representing situations which would be impossible to create in any other way.

3. Helping students to associate what they hear with his real life experience.

4. Time efficacy

5. Interest stimulation 


\section{Conclusion}

Overall, students of experiment and control group have the almost adequate scores in the pre test (70.75 and 72.625 respectively). However, in the post test, students of experiments group are scored much better than the other group (82.875 and 76 chronologically). Furthermore, based on statistical computation, there is significant difference between students taught by picture and those are not. In other word, picture is one of the best ways to teach vocabulary effectively, especially for the junior high school students.

\section{References}

Mackey, W.F. 1965. Language Teaching Analysis. London: London Laval University Press.

Kriedler, Carol J. Visual Aids for Teaching English to Speaker of Other Languages. Washington DC: United State Information Agency.

Hornby, A.S. 1987. Oxford Advanced Learners Dictionary of Current English. London: London Oxford University Press.

Lado, Robert. 1961. Language Teaching. New York: Mc. Graw Hill Inc. 